\title{
Coulisses
}

Revue de théâtre

6 | Printemps 1992

Varia

\section{Deux interprètes du rôle de Néron : Floridor et Talma}

\section{(2) OpenEdition}

Journals

Édition électronique

URL : http://journals.openedition.org/coulisses/1955

DOI : 10.4000/coulisses. 1955

ISSN : 2546-9460

Éditeur

Presses universitaires de Franche-Comté

\section{Édition imprimée}

Date de publication : 1 juin 1992

ISSN : 1150-594X

\section{Référence électronique}

"Deux interprètes du rôle de Néron : Floridor et Talma », Coulisses [En ligne], 6 | Printemps 1992, mis en ligne le 15 mars 2019, consulté le 23 octobre 2019. URL : http://journals.openedition.org/coulisses/ 1955 ; DOI : 10.4000/coulisses. 1955

Ce document a été généré automatiquement le 23 octobre 2019.

Coulisses 


\section{Deux interprètes du rôle de Néron : Floridor et Talma}

\section{Floridor (1608-1671)}

1 De son vrai nom Josias de Soulas, Floridor est un comédien d'authentique noblesse qui fut l'un des plus grands tragédiens de son temps. Il entra dès 1638 au Théâtre du Marais où il fut le créateur des rôles titres des tragédies de Corneille (Cinna, Horace...) alors dans toute sa gloire. Il quitta le Marais en avril 1647 pour diriger le Théâtre de l'Hôtel de Bourgogne. Il présida aux destinées de la troupe jusqu'en 1671.

2 Comme d'autres grands acteurs tels Montfleury, la Champmeslé, Floridor jouit de l'estime royale : «Floridor était particulièrement connu du Roi, qui le voyait de bon œil et daignait le favoriser en toutes rencontres » (Chappuzeau, Théâtre français, 1674). 


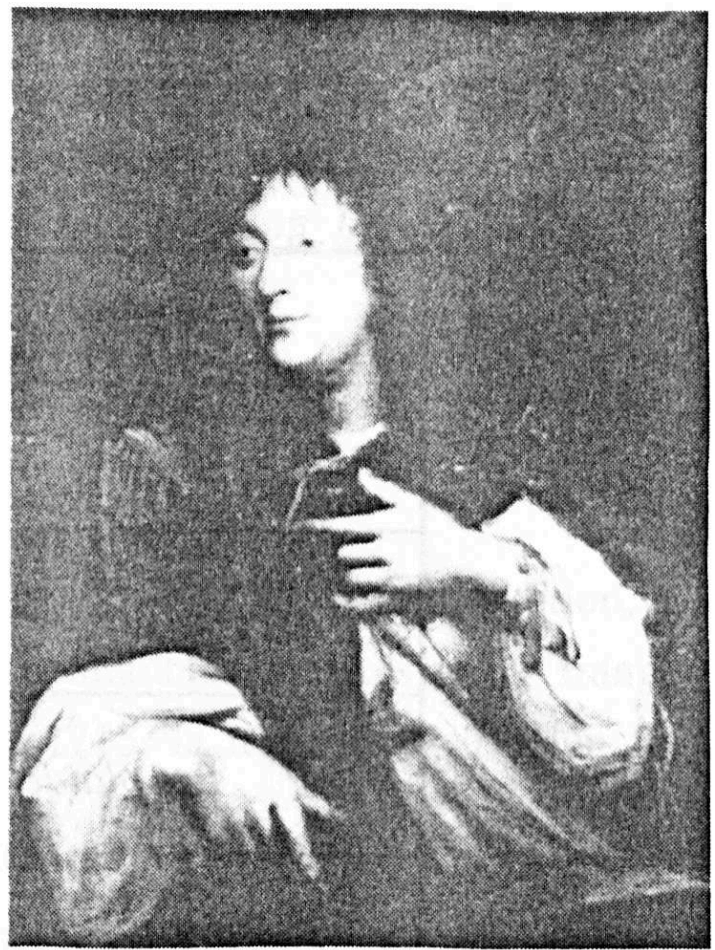

3 Il fut l'interprète des tragédies de Racine, créant les rôles d'Alexandre, Néron, Titus... Lorsqu'il crée le rôle de Néron, il a 61 ans, c'est peu dire qu'il n'a pas l'âge du personnage mais il est le plus grand acteur du moment. «Le rôle de Néron, dit la chronique, était joué par Floridor, le meilleur comédien de son siècle; mais, comme c'était un acteur aimé du public, tout le monde souffrait de lui voir représenter Néron et d'être obligé de lui vouloir du mal. Cela fut cause qu'on donna le rôle à un acteur moins chéri, et la pièce s'en trouva mieux » (Bolaena).

\section{Talma François-Joseph (1763-1826)}

Rien en apparence ne destinait Talma au métier de comédien. Sur les traces de son père, il entreprend des études pour être dentiste, fait son apprentissage à Londres où il découvre le théâtre de Shakespeare. De retour en France, il entre à vingt-trois ans au Conservatoire National de Musique et de Déclamation et débute dès l'année suivante à la Comédie-Française. En 1789, il sera nommé sociétaire.

Doté d'une puissante personnalité, Talma entreprend de renouveler les pratiques théâtrales de son époque. Sur les indications du peintre David, il fait exécuter des costumes authentiquement romains dessinés d'après les médailles et les statues antiques. Dans un identique souci d'authenticité, il renonce aux perruques et adopte une coiffure courte et non poudrée. Stendhal qui place Talma au premier rang des comédiens de son temps, écrit en 1804 : «Les plus grands peintres n'ont point de plus belles attitudes et de plus belles têtes ».

6 Talma donnait à ses interprétations une intensité émotionnelle et une puissance dramatique qui enflammaient les spectateurs. Joseph-Isidore Samson, acteur et professeur d'art dramatique, a laissé un témoignage sur la manière dont Talma jouait 
l'entrée en scène de Néron (II, 1). Lorsqu'il ordonnait qu'on exile Pallas, "sa parole courait impétueuse et brève ». En contraste, «Vous, Narcisse, approchez » était dit d'un ton caressant, la fin du vers «Et vous, qu'on se retire » était accompagnée d'un geste puissant. Talma avait un débit rapide, expression d'un impérial courroux, et, par le jeu des accents d'insistance, certains mots « détachés du reste de la phrase se dressaient plus fougueux, plus fiers, plus menaçants ».

Talma, dans le rôle de Néron

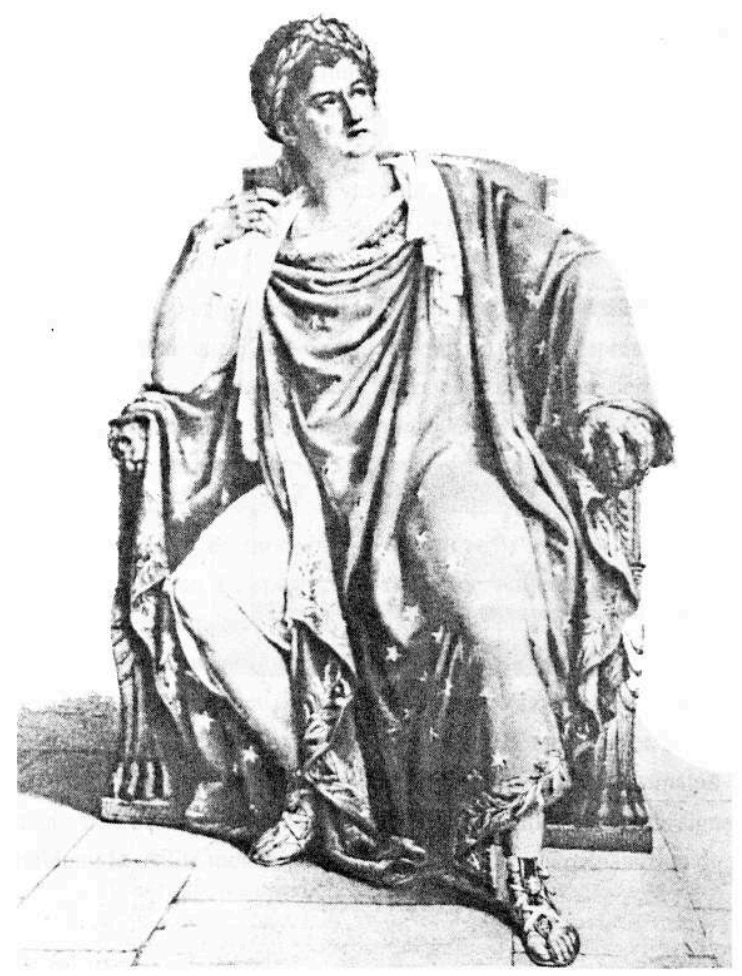

Lithographie de l'époque 